\title{
Adipose tissue in COVID-19: detection of SARS-CoV-2 in adipocytes and activation of the interferon-alpha response
}

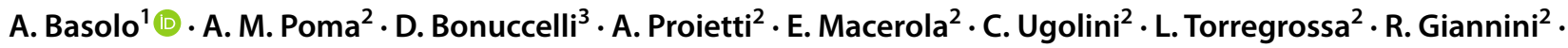

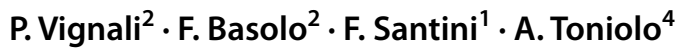

Received: 29 December 2021 / Accepted: 7 January 2022 / Published online: 15 February 2022

(c) The Author(s) 2022

\begin{abstract}
Objective Obesity is a recognized risk factor for the progression to severe forms of COVID-19, yet the mechanisms of the association are unclear.

Methods Subcutaneous abdominal adipose tissue specimens of subjects deceased from COVID-19 $(n=23)$ were compared to those of controls dying abruptly from causes other than infectious (accidental trauma, sudden cardiac death). Alterations of lung parenchyma consistent with moderate to severe disease were detected in all COVID-19 cases, not in controls. Investigations included: histopathologic features, detection of virus antigens and genome, characterization of infiltrating leukocytes, transcription levels of immune-related genes.

Results By RT-PCR, the SARS-CoV-2 genome was detected in the adipose tissue of 13/23 (56\%) cases of the COVID-19 cohort. The virus nucleocapsid antigen was detected in the cytoplasm of 1-5\% adipocytes in 12/12 COVID-19 cases that were virus-positive by PCR in the adipose tissue (one case could not be assessed due insufficient tissue). The adipose tissue of COVID-19 cases showed leukocyte infiltrates and upregulation of the interferon-alpha pathway. After adjusting for age and sex, the activation score of IFN-alpha was directly related with transcription levels of the ACE2 gene, a key entry factor of SARS-CoV-2.

Conclusions In lethal COVID-19 cases, the SARS-CoV-2 nucleocapsid antigen has been detected in a sizeable proportion of adipocytes, showing that the virus may directly infect the parenchymal cells of subcutaneous fat. Infection appears to activate the IFN alpha pathway and to attract infiltrating leukocytes. Due to the huge numbers of adipocytes in adults, the adipose tissue represents a significant reservoir for SARS-CoV-2 and an important source of inflammatory mediators.
\end{abstract}

Keywords COVID-19 · Pathogenesis · Virus · Immune transcriptome · Interferon · BMI · Autopsy

\begin{tabular}{|c|c|}
\hline \multicolumn{2}{|c|}{ Abbreviations } \\
\hline FFPE & Formalin-fixed and paraffin-embedded \\
\hline BMI & $\begin{array}{l}\text { Body mass index (weight in kilograms } \\
\text { divided by the square of height in meters) }\end{array}$ \\
\hline IFN & Interferon \\
\hline ACE2 & Angiotensin-converting enzyme-2 \\
\hline TMPRSS2 & Transmembrane serine protease 2 \\
\hline CTSL & Cathepsin L \\
\hline PKR & RNA-dependent protein kinase \\
\hline EIF2S1 & $\begin{array}{l}\text { Eukaryotic translation initiation factor } 2 \\
\text { subunit alpha }\end{array}$ \\
\hline FCAR & Immunoglobulin alpha Fc receptor \\
\hline
\end{tabular}

A. Basolo

alessio.basolo@med.unipi.it

Extended author information available on the last page of the article

\section{Introduction}

The white adipose tissue (WAT) communicates with other tissues to regulate metabolism both centrally and peripherally through secretion of adipocyte-derived peptide hormones, inflammatory mediators and signaling lipids [1-3]. WAT is an essential regulator of energy storage and systemic metabolic homeostasis. One of its endocrine functions is the conversion of androstenedione to estrone, the major source of estrogen in men and post-menopausal women [4]. In addition to releasing regulators of glucose and lipid metabolism, WAT cells (adipocytes, stromal cells, resident innate lymphoid cells, dendritic cells, monocyte-derived macrophages) produce hormones (e.g., leptin, adiponectin, resistin, apelin), growth factors (e.g., FGF21, BMPs, TGF-beta, VEGFs, PDGF) and cytokines (e.g., TNF, IL6, IL13, CCL2)[1, 2]. 
Obesity has been recognized as a risk factor for progression to severe forms of COVID-19 [5]. The mechanisms underlying the link between obesity and disease severity upon infection with SARS-CoV-2 remain, however, unclear. In principle, obesity could contribute in multiple ways to the evolution of infection: (a) down-modulating the antiviral responses [6]; (b) releasing lipids that promote endothelial dysfunction and sustain intravascular coagulation [7]; (c) disrupting leptin and insulin signaling, thus intensifying the inflammatory response [8]; (d) promoting enhanced expression of SARS-CoV-2 receptors [9]; (e) representing a large reservoir for virus replication with increased shedding of virus and inflammatory mediators [10].

Recently, Gao and colleagues [11] evaluated the risk of severe COVID-19 outcomes in patients with obesity. The findings showed a positive association between body mass index (BMI) and COVID-19 hospital admissions and deaths. For hospital admissions, risk began to increase linearly above a BMI of $23 \mathrm{~kg} / \mathrm{m}^{2}$, whereas the risk of death began to increase at slightly higher BMI of $28 \mathrm{~kg} / \mathrm{m}^{2}$, in keeping with the association between BMI and a wide range of causespecific mortality outcomes [12]. SARS-CoV-2 was detected in multiple endocrine tissues such as thyroid [13-15] and testis of subjects dying from COVID-19 [16]. In addition, a recent study has shown the association of high body mass index with an increased risk of developing COVID-19 [17].

Due to the increasing prevalence of obesity in developed countries [2,18], we aimed at investigating the effects of SARS-CoV-2 in abdominal fat of individuals who died from COVID-19. Autopsy specimens of subcutaneous WAT of 23 COVID-19 autopsy cases were compared to specimens of 12 cases of sudden death from non-infectious causes. Results show that SARS-CoV-2 antigens are expressed into adipocytes of COVID-19 cases, that inflammatory infiltrates are well represented, and that transcription of the angiotensinconverting enzyme-2 (ACE2) key entry factor for the virus is upregulated in the infected adipose tissue. In addition, mRNA transcription of selected genes of the innate antiviral response is enhanced.

\section{Materials and methods}

\section{Investigated cases and study design}

As shown in Table 1, three case groups have been investigated: (a) controls, i.e., subjects who died from acute causes other than infectious (trauma, sudden cardiac death; $n=12$ ); (b) patients dying from COVID-19 (abdominal adipose tissue negative for SARS-CoV-2; $\mathrm{n}=10$ ); (b) patients dying from COVID-19 (abdominal adipose tissue positive for SARS-CoV- $2 ; n=13)$. Results refer to subjects of Caucasian ethnicity. Autopsies have been performed at the Unit of Forensic Medicine, Azienda USL Toscana Nordovest, Lucca, Italy. The recruitment area of the Institution includes four major City Hospitals: Lucca, Pisa and Massa-Carrara caring for approximately 1.3 million populations.

At autopsy, all cases were screened for the SARS-CoV-2 genome in the inferior lobe of both lungs as well as in the abdominal adipose tissue. As previously reported [14], alterations of lung parenchyma consistent with moderate to severe disease were detected in all COVID-19 cases, not in controls. Adipose tissue specimens of COVID-19 cases were compared to those of controls with regard to histopathological features (Fig. 1A and B), transcription levels of immunerelated genes, infiltrating leukocyte markers, expression of SARS-CoV-2 antigens, and detection of SARS-CoV-2 genome by gene amplification. The study was approved by the local Ethical Committee (Comitato Etico Area Vasta Nord-Ovest, Italy No. 17327, 2020-05-14).

\section{Detection of viral genome and analysis of gene transcription}

For each specimen, total RNA was extracted from four $10 \mu \mathrm{m}$-thick FFPE sections of abdominal WAT using the RNeasy FFPE kit (Qiagen, Hilden, Germany) and quantified by spectrophotometry (Trinean, Gentbrugge, Belgium). About $250 \mathrm{ng}$ of RNA were used for each RT-PCR test to detect two genes of SARS-CoV-2 [viral nucleocapsid (N) and RNA-dependent RNA Polymerase (RdRp)] using the SARS-CoV-2 WE kit (Diatech Pharmacogenetics, Jesi, Italy). All samples were run in duplicate. Results were deemed positive when amplicons were obtained from at least one of the two genes. To evaluate the expression of viral nucleocapsid antigens and PKR by immunohistochemistry (IHC), 30 randomly selected high power (40x) fields were scanned, and the percentage of stained cells was calculated.

Gene expression analysis was performed by the nCounter technology (nanoString Technologies, Seattle, WA, USA) using two panels: (a) the Host Immune Response panel; (b) the Coronavirus panel plus that contains probes targeting the $\mathrm{N}$ and S ORFs of HCoV-229E, HCoV-HKU1, HCoV-NL63, HCoV-OC43, SARS-CoV, and the ACE2 virus receptor. Probes for the SARS-CoV-2 virus were designed according to the reference sequence, Wuhan-Hu-1 (NC_045512). For the assay, about $250 \mathrm{ng}$ of RNA were hybridized with probes at $65{ }^{\circ} \mathrm{C}$ for $21 \mathrm{~h}$. Procedures were performed following the manufacturer's protocol.

\section{Immunohistochemistry}

Immunostaining for viral proteins was performed in all cases except for one case that was not assessed due insufficient tissue. Markers of immune cells have been determined in 11/12 controls, 7/10 COVID-19 cases virus-negative in 
Table 1 Demographic, clinical and virological features of the investigated autopsy cases

\begin{tabular}{|c|c|c|c|}
\hline \multirow[t]{2}{*}{ Features } & \multirow{2}{*}{$\begin{array}{l}\text { Controls }(n=12) \\
\text { SARS-CoV-2-nega- } \\
\text { tive }(n=12)\end{array}$} & \multicolumn{2}{|l|}{ COVID-19 patients $(n=23)$} \\
\hline & & $\begin{array}{l}\text { SARS-CoV-2-negative in } \\
\text { adipose tissue }(n=10)\end{array}$ & $\begin{array}{l}\text { SARS-CoV-2-positive } \\
\text { in adipose tissue } \\
(n=13)\end{array}$ \\
\hline \multicolumn{4}{|c|}{ Detection of SARS-CoV-2 by RT-PCR } \\
\hline Lungs & - & + & + \\
\hline Adipose tissue & - & - & + \\
\hline \multicolumn{4}{|l|}{ Age (years) } \\
\hline Mean (SD) & $57.2(20.3)$ & $64.5(19.2)$ & $74(14.6)$ \\
\hline \multicolumn{4}{|l|}{ Gender } \\
\hline Male & $8(67 \%)$ & $5(50 \%)$ & $11(85 \%)$ \\
\hline Female & $4(33 \%)$ & $5(50 \%)$ & $2(15 \%)$ \\
\hline \multicolumn{4}{|l|}{$B M I$} \\
\hline Normal & $9(75 \%)$ & $2(20 \%)$ & $6(46 \%)$ \\
\hline Overweight/obesity & $3(25 \%)$ & $8(80 \%)$ & $7(54 \%)$ \\
\hline \multicolumn{4}{|l|}{ Comorbidities } \\
\hline Cardiovascular disease & $6(50 \%)$ & $4(40 \%)$ & $8(62 \%)$ \\
\hline Chronic pulmonary disease & 0 & $3(30 \%)$ & $1(8 \%)$ \\
\hline Diabetes & $1(8 \%)$ & $2(20 \%)$ & $4(31 \%)$ \\
\hline Malignancy & 0 & $1(10 \%)$ & $1(8 \%)$ \\
\hline Hypokinesia & 0 & 0 & $1(8 \%)$ \\
\hline None & $5(42 \%)$ & $4(40 \%)$ & $3(23 \%)$ \\
\hline \multicolumn{4}{|c|}{ Days from COVID-19 symptoms to death } \\
\hline Mean $( \pm \mathrm{SD})$ & N.A & $15.9(17)$ & $7.2(5.4)^{*}$ \\
\hline
\end{tabular}

*After adjusting for age, sex and BMI, Cox regression showed that SARS-CoV-2 positivity of subcutaneous WAT is associated with a reduced survival time from initial symptoms (HR 3.7, 95\%CI 1.1-12.5, $p=0.03$ )

$B M I$ body mass index $\left(\mathrm{kg} / \mathrm{m}^{2}\right)$

WAT, 11/13 COVID-19 cases virus-positive in WAT. In some cases, the analysis could not be performed due to insufficient material. Three-micrometer-thick sections were stained with antibodies to SARS-CoV-2: rabbit polyclonal antibody to the nucleocapsid protein (NB100-56,683, Novus Biologicals, Centennial, CO, United States) and mouse monoclonal antibody to SARS-CoV-2 spike glycoprotein (GTX632304, GeneTex). Antibodies to immune cell markers (Roche Diagnostics, Ventana Medical Systems, Oro Valley, AZ, United States) comprised: CONFIRM anti-CD3 (2GV6) rabbit monoclonal, CONFIRM anti-CD20 (L26) mouse monoclonal, CONFIRM anti-CD45, LCA (RP2/18) mouse monoclonal, CONFIRM anti-CD68 (KP-1) mouse monoclonal, anti-CD57 (NK1) mouse monoclonal, CONFIRM antiCD15 (MMA) mouse monoclonal. Staining for the human RNA-dependent protein kinase (PKR) was performed using a PKR rabbit polyclonal antibody (Invitrogen-ThermoFisher Scientific; 1:50 dilution, incubation at $36{ }^{\circ} \mathrm{C}$ for $48 \mathrm{~min}$ ). Sections of normal human kidney were used as positive control [19]. Staining procedures were performed with an automated staining system (BenchMark ULTRA, Ventana Medical Systems). Antibody binding was revealed with the OptiView DAB IHC Detection Kit (Ventana Medical
Systems). Slides were counterstained with Hematoxylin II and Bluing Reagent (Ventana Medical Systems). Counts of immune markers were performed independently by two pathologists (A.P. and F.B). Twenty randomly selected fields were scanned at $20 \times$ magnification. IHC score: cell counts represent the mean numbers of cells persquare $\mathrm{mm}$.

\section{Data analysis}

Raw data of gene transcripts were normalized using the Advanced Analysis module of the nSolver v.4.0 (nanoString Technologies). Low count genes defined as those with raw expression level as low as 20 counts were omitted. Normalized gene expression levels were $\log 2$ transformed for further analysis. The principal component analysis (PCA) was performed by the procedures of the PCAtools Bioconductor package v.3.12 after removing $10 \%$ of genes with the lowest variance. Differentially expressed genes (DEG) were computed by a linear model adjusting for age, sex and BMI, and using the Advanced Analysis module of nSolver. In detail, control cases were used as baseline and three comparisons were done: all COVID-19 cases $v s$ baseline; COVID-19 
Fig. 1 Histopathology and immunostaining of subcutaneous adipose tissue of COVID-19 autopsy cases. A H\&E staining of adipose tissue from a control case (40X); B H\&E staining showing leucocyte infiltration in a COVID-19 case positive for SARS-CoV-2 in adipose tissue (40X). Immunostaining: C nucleocapsid protein in the cytoplasm of two adipocytes (black arrows; 60X); D staining for pan-leukocyte marker CD45 (40X); $\mathbf{E}$ staining for the CD3 marker shows T-cells infiltrating the tissue (40X); $\mathbf{F}$ staining for CD68: black arrows show macrophage infiltration (60X). G staining for CD57: black arrows show natural killer cells (60X); $\mathbf{H}$ absence of staining for CD20 indicates the lack of infiltrating B-cells in SARS-CoV-2 positive adipose tissue (20X); $\mathbf{I}$ and $\mathbf{L}$ expression of the interferoninduced PKR protein in the cytoplasm of adipocytes of two different COVID-19 cases (60X); L, inset) PKR-positive control: marked PKR staining in the cytoplasm of tubular cells in normal human kidney
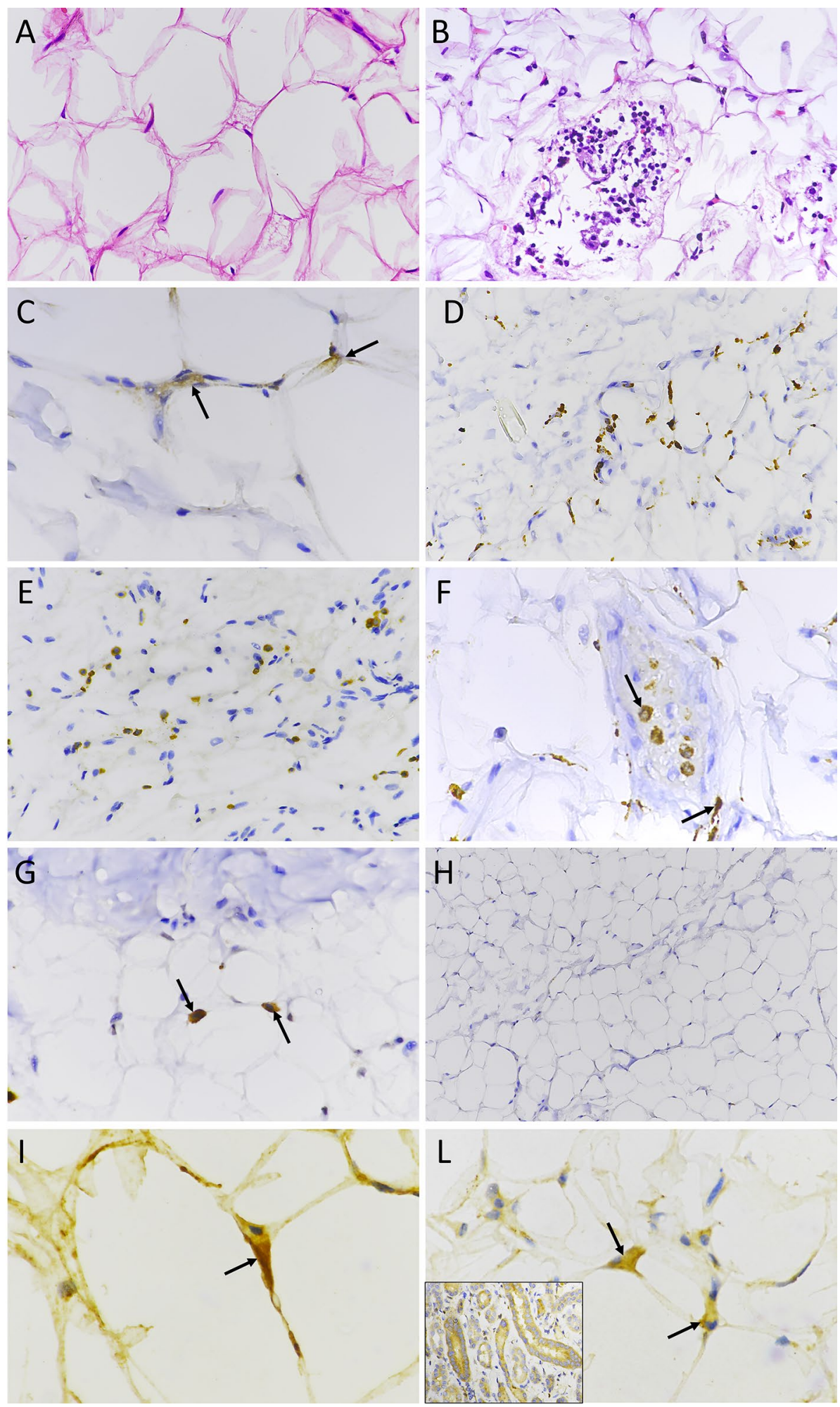

cases with no virus detected in WAT $v s$ baseline; COVID19 cases with SARS-CoV-2 detected in WAT $v s$ baseline.

The IFN $\alpha$ score was computed by single sample Gene Set Enrichment Analysis (ssGSEA) using the procedures of the GSVA Bioconductor package v.1.38.2. The method described by Barbie [20] was used. Gene Set Enrichment Analysis (GSEA) was run using the ranked gene list of differential expression analyses and following the procedures of the clusterProfiler Bioconductor package v.3.18.1. For analysis, ten was used as minimum gene set size cut-off, and the 
Hallmark collection of the Molecular Signatures Database (MSigDB) v.7.4 behaved as a reference [21] . Gene functions are reported according to the human gene databases GenCards and OMIM.

Survival times after initial symptoms were analyzed by Cox regression both in univariate and multivariate setting following the procedures of the survival R package v.3.2-13. Linear regression analysis was performed to evaluate the relationships among BMI and transcripts for SARS-CoV-2 entry molecules (ACE2, TMPRSS2, FURIN), as well as those between BMI and IFN alpha score. Pearson's correlation coefficient was then calculated to quantify the associations of BMI and IFN-alpha score after adjusting for age and sex. Scatter plot were generated after partial regression. Analyses and plots were generated in R environment (https:// www.r-project.org/, v.4.0.2, last accessed May 10, 2021) and with Prism (GraphPad Software, San Diego, CA).

\section{Results}

\section{Nucleocapsid antigen of SARS-CoV-2}

The demographic and clinical data of the investigated autopsy groups are shown in Table 1. Compared to controls (sudden death from trauma or sudden cardiac arrest), overweight or obesity were more frequent among COVID19 cases $(p=0.03)$. All COVID-19 patients were positive for the SARS-CoV-2 genome in lungs. Among COVID-19 cases, however, the virus genome was detected in abdominal WAT of 13/23 (56\%) subjects. Uninfected controls and COVID-19 cases whose WAT was SARS-CoV-2-negative by PCR were not stained by antibodies to the virus nucleocapsid antigen. Conversely, 12/12 COVID-19 cases whose WAT was virus-positive by PCR showed granular cytoplasmic staining in 1-5\% adipocytes. Due to insufficient material, one SARS-CoV-2-positive case by PCR could not be assessed by IHC (Fig. 1C). In the same specimens, the antibody to the SARS-CoV-2 spike glycoprotein produced diffused staining that did not allow the precise localization of the viral protein (data not shown).

The nCounter system - based on the direct hybridization of probes without amplification steps-could detect the virus genome in 7/13 (54\%) WAT specimens of COVID-19 cases that were virus-positive by PCR in abdominal fat. In the latter cases, hybridization occurred with probes targeting SARS-CoV-2, not with probes specific for other coronaviruses (HCoV-229E, HCoV-HKU1, HCoV-NL63, HCoVOC43, SARS-CoV). As expected, hybridization failed to detect coronaviruses in WAT of controls and of COVID-19 cases whose WAT was virus-negative by PCR.

Finally, it was evaluated whether SARS-CoV-2 positivity in subcutaneous WAT impacted survival times. Using a univariate setting, the association was not statistically significant $(p=0.13)$. However, upon adjustment for age, sex and BMI, detection of SARS-CoV-2 in subcutaneous WAT was associated with a reduced survival time from initial symptoms (HR 3.7, 95\% CI 1.1-12.5, $p=0.03$ ).

\section{Leukocyte infiltrates and expression of RNA-dependent protein kinase (PKR) as a marker of IFN activation}

Inflammatory infiltrates were evaluated by staining for leukocyte markers. Compared to controls and to COVID19 specimens that were negative for virus in WAT, viruspositive specimens showed significantly increased numbers of cells expressing CD45 pan-leukocyte marker $(p<0.01)$ (Fig. 1D), CD3 T-cells ( $p<0.05$ ) (Fig. 1E), CD57 natural killer cells $(p<0.05)$ (Fig. 1F), and CD68 macrophages $(p<0.05)$ (Fig. 1G) (Fig. 2). CD20 B-cell leukocytes could not be detected in any groups (Fig. 1H).

Expression of the interferon-induced PKR protein (whose activated form phosphorylates the Eukaryotic Translation Initiation Factor 2 Subunit Alpha (EIF2S1) which, in turn, inhibits protein synthesis) was evaluated by immunostaining [19]. Compared to the control group, WAT specimens of all COVID-19 cases showed significantly increased numbers of adipocytes expressing PKR, no matter if WAT specimens were virus-positive or virus-negative (Fig. $1 \mathrm{I}, \mathrm{L}$ ). In COVID-19 cases, each high-power field (40x) comprised 2-6 PKR-positive adipocytes. This was significantly different $(P<0.05)$ from what observed in controls which had

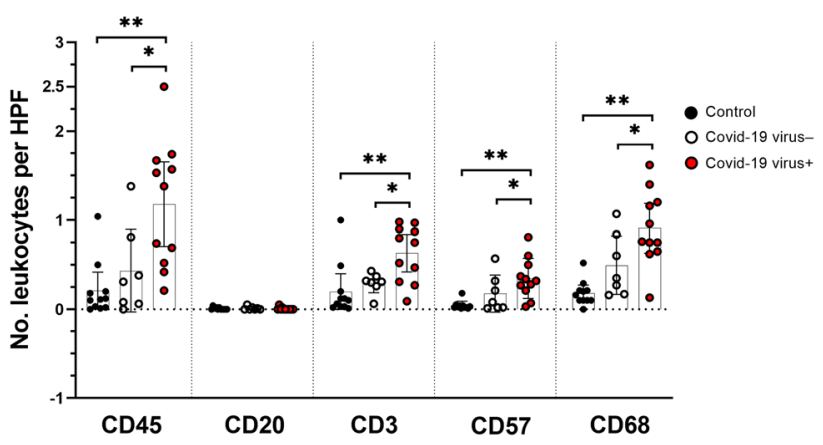

Fig. 2 Numbers of leukocytes per high power field (HPF) as evaluated by immunohistochemistry in subcutaneous adipose tissue. IHC scores for the following markers: CD45 (pan-leukocyte), CD20 (B cells), CD3 (T cells), CD57 (NK cells), CD68 (macrophages). Vertical black lines show interquartile ranges; horizontal black lines indicate the median value. COVID-19 cases: virus-positive specimens of adipose tissue ( $n=11$, red dots), virus-negative specimens of adipose tissue ( $n=7$, white dots). Control cases ( $n=11$, black dots). Counts represent the mean leukocyte numbers per square $\mathrm{mm}$. In a few cases, leukocyte markers could not be determined due to insufficient material. $* p<0.05$ (case vs. the indicated group; Dunn's test for multiple comparisons). ${ }^{* *} p<0.001$ (case vs. the indicated group; Dunn's test for multiple comparisons) 
less than 0.3 PKR-positive cells per high power field (data not shown).

Sections of normal human kidney were used as positive control for PKR staining. As expected, PKR was highly expressed in the cytoplasm of kidney tubular cells (Fig. 1 L, inset).

\section{Gene expression analysis}

As compared to controls, COVID-19 cases showed no marked deregulations of immune gene transcripts. To highlight possible pathway deregulations in the presence of small fold changes, a GSEA analysis was performed Fig. 2. As compared to the control group, only the IFN-alpha pathway was significantly activated in virus-positive WAT specimens (FDR =0.009, Fig. 3). SARS-CoV-2 utilizes the ACE2 (and possibly other factors such as BSG, NRP1 and HSPA5) as cell entry factors together with the priming proteases TMPRSS2, CTSL, FURIN that facilitate virus entry [22]. In subcutaneous WAT, only transcripts of ACE2 and FURIN genes could be detected. Transcription of ACE2 was upregulated in COVID-19 cases. Interestingly, the IFN-alpha score was directly related to ACE2 transcripts levels after adjustment for age and sex (partial $r=0.53, p=0.0014$ ) (Fig. 4). Comparable results were observed also after adjustment for BMI (partial $r=0.47, p=0.006$ ). Furthermore, transcription of the immunoglobulin alpha Fc receptor (FCAR)) gene was

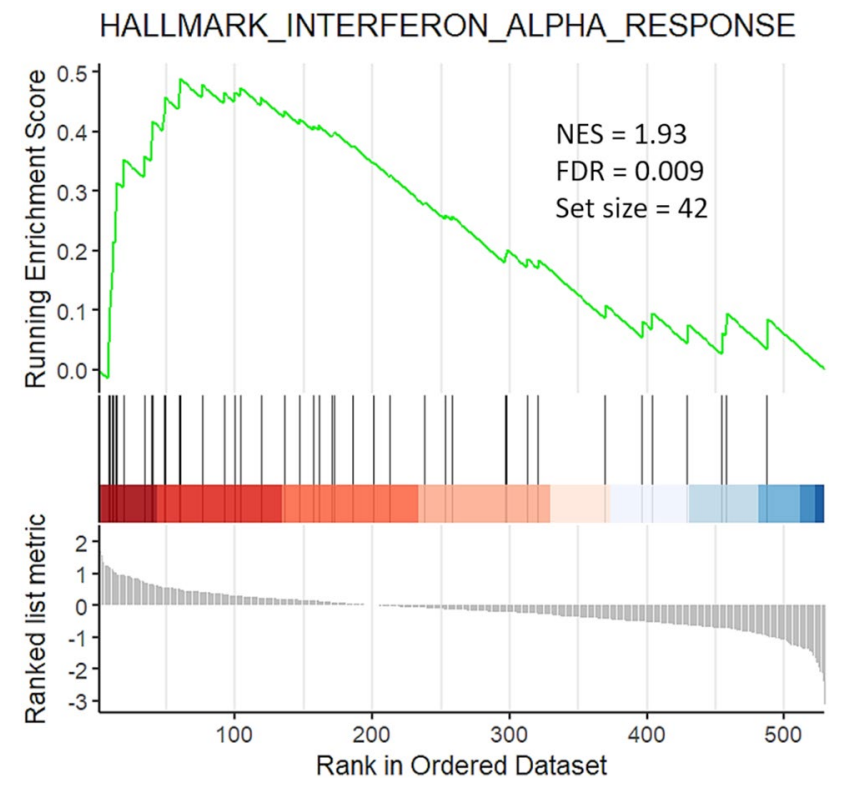

Fig. 3 Gene set enrichment analysis plot of adipose tissue specimens of COVID-19 cases vs. control cases. Compared to the control group $(n=12)$, the IFN-alpha pathway was activated in COVID-19 cases that were SARS-CoV-2-positive by PCR in adipose tissue (13 cases). Vertical black bars refer to genes activated upon IFN-alpha signaling and are shifted to the left indicating a positive fold change. Abbreviations: NES, normalized enrichment score; FDR, false discovery rate

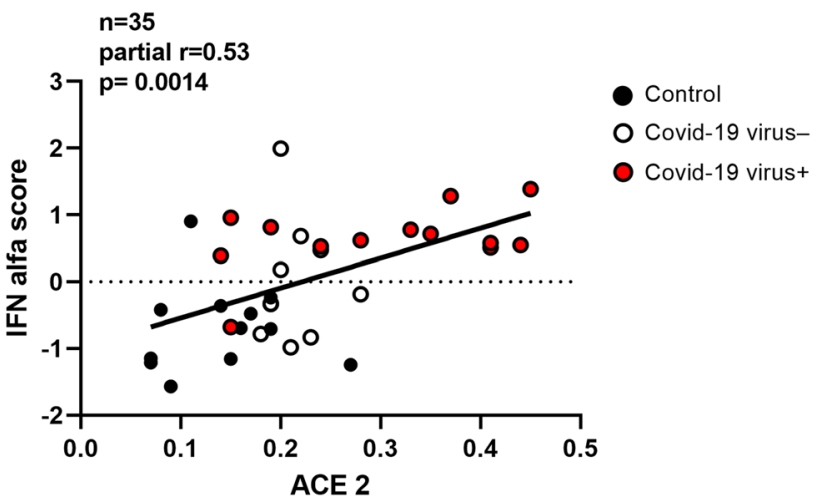

Fig. 4 Association of the IFN-alpha score with ACE2 transcription levels after adjustment for age and $\operatorname{sex}(n=35$, partial $R=0.53$, $p=0.0014)$

strongly downregulated, suggesting that SARS-CoV-2 plays some immunosuppressive role [23].

\section{Discussion}

Adipose tissue is very abundant in the human body. In adults, the total number of adipocytes in WAT is estimated in about 30 billion with a variable cell size according to age, sex and fat accumulation [24, 25]. The renewal rate is $5-10 \%$ per year $[26,27]$. The results of this study show that, at the time of death, the SARS-CoV-2 nucleocapsid antigen is expressed in 1 to 5\% adipocytes in the virus-positive subcutaneous WAT of COVID-19 cases. In addition, transcripts of the IFN-alpha pathway are upregulated while the transcription levels of ACE2 (but not FURIN and TMPRSS2) are associated with the degree of activation of the IFN-alpha pathway. Notably, expression of PKR (an important marker of IFN activation) was increased in all COVID-19 cases, no matter of SARS-CoV-2 positivity in WAT. The finding indicates that, once triggered, IFN-alpha-a circulating cytokine with a defensive action in uninfected cells-remains active for substantial periods of time stimulating PKR expression [28].

In addition, IFN has been found to stimulate the expression of ACE2 in epithelial cells of the respiratory tract [29] and, more recently, proteomic analyses revealed that in COVID-19 patients, different entry factors of SARSCoV-2 are comprised in upregulated pathways [30]. Our results show that SARS-CoV-2 infection of WAT is associated with enhanced transcription of ACE2. A condition of this type has been reported in chronic lung diseases that appear to stimulate gene expression programs promoting both the cellular entry of SARS-CoV-2 and the severity of COVID-19 [22]. Comparable mechanisms can be acting in obesity, since the condition is associated with unapparent 
inflammation [31]. Different WAT-associated endocrine mechanisms have been proposed: (a) high plasma resistin levels are strong predictors of mortality in COVID-19 [32]; (b) high serum leptin levels are associated with increased expression of ACE2 and of leptin receptors in lungs [33]; (c) reduced plasma adiponectin levels associate with respiratory failure in COVID-19 patients (also upon adjustment for age, sex and BMI) indicating a role for adiponectin in the linking of obesity with COVID-19 [34].

Our data also indicate that a sizeable number of adipocytes participate in the production of SARS-CoV-2. As widely reported, virus replication is consistently related to the release of inflammatory factors and cytokines [32, 35, 36]. In COVID-19, a functional ACE2 deficiency has been proposed to cause angiotensin imbalance with the consequent reduction of the ACE2-RAS system that might worsen the prognosis in obese patients [37]. Regarding the possible immunosuppressive activity of SARS-CoV-2 [36], downregulation of the FCAR gene was the only evidence obtained in our study of WAT. FCAR is expressed in leukocytes, mediates resistance to a wide range of pathogens and stimulates cytokine production [38].

Our study has several limitations. Since observations have been performed on autopsy specimens, the data refer only to the time of death and no information may be given regarding the early or intermediate phases of disease. Also, for safety reasons at the time of autopsy, only subcutaneous WAT was sampled, not visceral WAT, though the latter greatly contributes to overweight and obesity, two recognized risk factors for severe forms of COVID-19. An additional limitation is that-due to autolytic processes in autoptic specimensthe virus could be detected only by immunostaining for the nucleocapsid antigen, not by the more sensitive method of in situ hybridization (ISH) that detects the virus genome [39, 40]. Of note, a previous study of autoptic specimens using ISH and IHC could not detect the virus in adipose tissue and other extra-pulmonary organs [41]. Studies of adipose tissue obtained from living patients would greatly contribute to the field. Also, though this is the first demonstration of SARS COV-2 infection of WAT, the sample size is relatively small. Further studies are needed to clarify the mechanisms underlying the worse clinical outcome in patients with obesity and must include the study of visceral WAT. Lastly, given the relatively high prevalence of cases carrying SARS-CoV-2 in WAT, it should be noted that results refer only to lethal COVID-19 cases. Hence, in less severe cases, virus positivity in WAT cells could be lower.

In conclusion, the data indicate that adipocytes express SARS-CoV-2 protein antigens, that infection activates an IFN response, that the tissue is infiltrated by NK cells, macrophages and $\mathrm{T}$ cells. Thus, the adipose tissue directly participates in the disease process and-due to its large size-represents a significant reservoir for virus, an important source of inflammatory mediators, and a possible target for lipophilic drugs.

Acknowledgements The study has been conducted in collaboration with the Centro Linceo Beniamino Segre, Accademia dei Lincei, Rome, Italy and the Global Virus Network (GVN), Baltimore, MD.

Author contributions Conceptualization, A.B., A.T., F.B., A.M.P.; clinical work and autopsy samples: D.B., A.B.; F.C., F.B.; methodology, A.B., A.M.P., F.B., A.T., A.P., E.M., C.U., L.T., R.G., P.V.; formal analysis, A.B., A.T., A.M.P., D.B.; resources, F.B., A.T.; preparation of the original draft, A.B., A.T., F.B., A.M.P.; writing, review and editing, A.T., A.B., F.B., A.M.P., D.B., L.T.; project administration, F.B., A.T.; funding acquisition, F.B., A.T. All authors have read, revised and approved the final version of the manuscript.

Funding The study was funded by: Tuscany Region (PRE-MED2, Progetto Salute 2018 to F.B.), the Juvenile Diabetes Research Foundation \& nPOD-V (JDRF grant 25-2012-770 to AT), the Italian Ministry of Health (grant PE-2013-02357094 to A.T.).

\section{Declarations}

Conflicts of interest A.B. and F.S. are members of the editorial board of the Journal of Endocrinological Investigation. The other authors declare no conflict of interest. The funders had no role in the design of the study; in the collection, analyses, or interpretation of data; in writing the manuscript, or in the decision to publish the results.

Ethical approval The study has been approved by the local Ethical Committee (Comitato Etico Area Vasta Nord-Ovest, Lucca, Italy No. $17327,2020-05-14)$. The procedures employed in the study are in accordance with the ethical standards of the Local Ethical Committee and with the 1964 Helsinki Declaration and its later amendments.

Informed consent For this type of study, consent is not required.

Open Access This article is licensed under a Creative Commons Attribution 4.0 International License, which permits use, sharing, adaptation, distribution and reproduction in any medium or format, as long as you give appropriate credit to the original author(s) and the source, provide a link to the Creative Commons licence, and indicate if changes were made. The images or other third party material in this article are included in the article's Creative Commons licence, unless indicated otherwise in a credit line to the material. If material is not included in the article's Creative Commons licence and your intended use is not permitted by statutory regulation or exceeds the permitted use, you will need to obtain permission directly from the copyright holder. To view a copy of this licence, visit http://creativecommons.org/licenses/by/4.0/.

\section{References}

1. Kahn CR, Wang G, Lee KY (2019) Altered adipose tissue and adipocyte function in the pathogenesis of metabolic syndrome. $\mathrm{J}$ Clin Invest 129(10):3990-4000

2. Hildreth AD, Ma F, Wong YY, Sun R, Pellegrini M, O'Sullivan TE (2021) Single-cell sequencing of human white adipose tissue identifies new cell states in health and obesity. Nat Immunol 22(5):639-653 
3. Heinitz S, Basolo A, Piaggi P, Piomelli D, Jumpertz von Schwartzenberg R, Krakoff J. Peripheral Endocannabinoids Associated With Energy Expenditure in Native Americans of Southwestern Heritage. J Clin Endocrinol Metab. 2018;103(3):1077-87.

4. Hirsch J, Fried SK, Edens NK, Leibel RL (1989) The fat cell. Med Clin North Am 73(1):83-96

5. Kwok S, Adam S, Ho JH, Iqbal Z, Turkington P, Razvi S, Le Roux CW, Soran H, Syed AA (2020) Obesity: A critical risk factor in the COVID-19 pandemic. Clin Obes. 10(6):e12403

6. Ramasamy S, Subbian S (2021) Critical Determinants of Cytokine Storm and Type I Interferon Response in COVID-19 Pathogenesis. Clin Microbiol Rev 34(3):e00299

7. Gu SX, Tyagi T, Jain K, Gu VW, Lee SH, Hwa JM, Kwan JM, Krause DS, Lee AI, Halene S, Martin KA, Chun HJ, Hwa J (2021) Thrombocytopathy and endotheliopathy: crucial contributors to COVID-19 thromboinflammation. Nat Rev Cardiol 18(3):194-209

8. de Leeuw AJM, Oude Luttikhuis MAM, Wellen AC, Müller C, Calkhoven CF (2021) Obesity and its impact on COVID-19. J Mol Med (Berl). https://doi.org/10.1007/s00109-021-02072-4:1-17

9. Balkhi MY (2021) Mechanistic understanding of innate and adaptive immune responses in SARS-CoV-2 infection. Mol Immunol 135:268-275

10. Ryan PM, Caplice NM (2020) Is Adipose tissue a reservoir for viral spread, immune activation, and cytokine amplification in coronavirus disease 2019? Obesity (Silver Spring) 28(7):1191-1194

11. Gao M, Piernas C, Astbury NM, Hippisley-Cox J, O'Rahilly S, Aveyard P, Jebb SA (2021) Associations between body-mass index and COVID-19 severity in 6.9 million people in England: a prospective, community-based, cohort study. Lancet Diabetes Endocrinol 9(6):350-359

12. Bhaskaran K, Dos-Santos-Silva I, Leon DA, Douglas IJ, Smeeth L (2018) Association of BMI with overall and cause-specific mortality: a population-based cohort study of 3.6 million adults in the UK. Lancet Diabetes Endocrinol 6(12):944-953

13. Rotondi M, Coperchini F, Ricci G, Denegri M, Croce L, Ngnitejeu ST, Villani L, Magri F, Latrofa F, Chiovato L (2021) Detection of SARS-COV-2 receptor ACE-2 mRNA in thyroid cells: a clue for COVID-19-related subacute thyroiditis. J Endocrinol Invest 44(5):1085-1090

14. Poma AM, Basolo A, Bonuccelli D, Proietti A, Macerola E, Ugolini C, Torregrossa L, Alì G, Giannini R, Vignali P, Santini F, Toniolo A, Basolo F (2021) Activation of type I and type II interferon signaling in SARS-CoV-2-positive thyroid tissue of patients dying from COVID-19. Thyroid 31(12):1766-1775

15. Tanda ML, Ippolito S, Gallo D, Baj A, Novazzi F, Genoni A, Annoni M, Mancini N, Clementi N, Finzi G, Piantanida E, Premoli P, Lai A, Dalla GD, Maggi F, Uccella S (2021) SARS-CoV-2 detection in primary thyroid sarcoma: coincidence or interaction? J Endocrinol Invest. https://doi.org/10.1007/s40618-021-01722-1

16. Poma AM, Bonuccelli D, Giannini R, Macerola E, Vignali P, Ugolini C, Torregrossa L, Proietti A, Pistello M, Basolo A, Santini F, Toniolo A, Basolo F (2021) COVID-19 autopsy cases: detection of virus in endocrine tissues. J Endocrinol Invest. https://doi.org/ 10.1007/s40618-021-01628-y:1-6

17. Rizza S, Coppeta L, Grelli S, Ferrazza G, Chiocchi M, Vanni G, Bonomo OC, Bellia A, Andreoni M, Magrini A, Federici M (2021) High body mass index and night shift work are associated with COVID-19 in health care workers. J Endocrinol Invest 44(5):1097-1101

18. Ward ZJ, Bleich SN, Cradock AL, Barrett JL, Giles CM, Flax C, Long MW, Gortmaker SL (2019) Projected U.S. State-Level Prevalence of Adult Obesity and Severe Obesity. N Engl J Med 381(25):2440-2450

19. Pataer A, Raso MG, Correa AM, Behrens C, Tsuta K, Solis L, Fang B, Roth JA, Wistuba II, Swisher SG (2010) Prognostic significance of RNA-dependent protein kinase on non-small cell lung cancer patients. Clin Cancer Res 16(22):5522-5528

20. Barbie DA, Tamayo P, Boehm JS, Kim SY, Moody SE, Dunn IF, Schinzel AC, Sandy P, Meylan E, Scholl C, Fröhling S, Chan EM, Sos ML, Michel K, Mermel C, Silver SJ, Weir BA, Reiling JH, Sheng Q, Gupta PB, Wadlow RC, Le H, Hoersch S, Wittner BS, Ramaswamy S, Livingston DM, Sabatini DM, Meyerson M, Thomas RK, Lander ES, Mesirov JP, Root DE, Gilliland DG, Jacks T, Hahn WC. Systematic RNA interference reveals that oncogenic KRAS-driven cancers require TBK1. Nature. 2009 Nov 5;462(7269):108-12. https://doi.org/10.1038/nature08460. Epub 2009 Oct 21. PMID: 19847166;.

21. Liberzon A, Birger C, Thorvaldsdóttir H, Ghandi M, Mesirov JP, Tamayo P. The Molecular Signatures Database (MSigDB) hallmark gene set collection. Cell Syst. 2015 Dec 23;1(6):417425. doi: 10.1016/j.cels.2015.12.004. PMID: 26771021; PMCID: PMC4707969.

22. Bui LT, Winters NI, Chung MI, Joseph C, Gutierrez AJ, Habermann AC, Adams TS, Schupp JC, Poli S, Peter LM, Taylor CJ, Blackburn JB, Richmond BW, Nicholson AG, Rassl D, Wallace WA, Rosas IO, Jenkins RG, Kaminski N, Kropski JA, Banovich NE (2021) Chronic lung diseases are associated with gene expression programs favoring SARS-CoV-2 entry and severity. Nat Commun 12(1):4314

23. Pincetic A, Bournazos S, DiLillo DJ, Maamary J, Wang TT, Dahan R, Fiebiger BM, Ravetch JV (2014) Type I and type II Fc receptors regulate innate and adaptive immunity. Nat Immunol 15(8):707-716

24. Basolo A, Shah MH, Parthasarathy V, Parrington S, Walter M, Votruba SB, Krakoff J, Piaggi P, Chang DC (2020) Thigh adipocyte size is inversely related to energy intake and respiratory quotient in healthy women. Obesity (Silver Spring) 28(6):1129-1140

25. Basolo A, Poma AM, Giannini R, Ceccarini G, Pelosini C, Fierabracci P, Castany MU, Bechi Genzano S, Ambrosini CE, Materazzi G, Chiovato L, Basolo F, Santini F, Torregrossa L (2021) Histological pattern and gene expression profiling of thyroid tissue in subjects with obesity. J Endocrinol Invest. https:// doi.org/10.1007/s40618-021-01662-w

26. Knittle JL, Timmers K, Ginsberg-Fellner F, Brown RE, Katz DP (1979) The growth of adipose tissue in children and adolescents. Cross-sectional and longitudinal studies of adipose cell number and size. J Clin Invest 63(2):239-246

27. Spalding KL, Arner E, Westermark PO, Bernard S, Buchholz BA, Bergmann O, Blomqvist L, Hoffstedt J, Näslund E, Britton T, Concha H, Hassan M, Rydén M, Frisén J, Arner P (2008) Dynamics of fat cell turnover in humans. Nature 453(7196):783-787

28. Chumakov K, Avidan MS, Benn CS, Bertozzi SM, Blatt L, Chang AY, Jamison DT, Khader SA, Kottilil S, Netea MG, Sparrow A, Gallo RC (2021) Old vaccines for new infections: Exploiting innate immunity to control COVID-19 and prevent future pandemics. Proc Natl Acad Sci U S A 118(21):e2101718118

29. Ziegler CGK, Allon SJ, Nyquist SK, Mbano IM, Miao VN, Tzouanas CN, Cao Y, Yousif AS, Bals J, Hauser BM, Feldman J, Muus C, Wadsworth MH 2nd, Kazer SW, Hughes TK, Doran B, Gatter GJ, Vukovic M, Taliaferro F, Mead BE, Guo Z, Wang JP, Gras D, Plaisant M, Ansari M, Angelidis I, Adler H, Sucre JMS, Taylor CJ, Lin B, Waghray A, Mitsialis V, Dwyer DF, Buchheit KM, Boyce JA, Barrett NA, Laidlaw TM, Carroll SL, Colonna L, Tkachev V, Peterson CW, Yu A, Zheng HB, Gideon HP, Winchell CG, Lin PL, Bingle CD, Snapper SB, Kropski JA, Theis FJ, Schiller HB, Zaragosi LE, Barbry P, Leslie A, Kiem HP, Flynn JL, Fortune SM, Berger B, Finberg RW, Kean LS, Garber M, Schmidt AG, Lingwood D, Shalek AK, Ordovas-Montanes J (2020) SARS-CoV-2 Receptor ACE2 Is an Interferon-Stimulated 
Gene in Human Airway Epithelial Cells and Is Detected in Specific Cell Subsets across Tissues. Cell 181(5):1016-35.e19

30. Li Y, Schneider AM, Mehta A, Sade-Feldman M, Kays KR, Gentili M, Charland NC, Gonye AL, Gushterova I, Khanna HK, LaSalle TJ, Lavin-Parsons KM, Lilley BM, Lodenstein CL, Manakongtreecheep K, Margolin JD, McKaig BN, Parry BA, RojasLopez M, Russo BC, Sharma N, Tantivit J, Thomas MF, Regan J, Flynn JP, Villani AC, Hacohen N, Goldberg MB, Filbin MR, Li JZ (2021) SARS-CoV-2 viremia is associated with distinct proteomic pathways and predicts COVID-19 outcomes. J Clin Invest. https:// doi.org/10.1172/jci148635

31. Saltiel AR, Olefsky JM (2017) Inflammatory mechanisms linking obesity and metabolic disease. J Clin Invest 127(1):1-4

32. Meizlish ML, Pine AB, Bishai JD, Goshua G, Nadelmann ER, Simonov M, Chang CH, Zhang H, Shallow M, Bahel P, Owusu K, Yamamoto Y, Arora T, Atri DS, Patel A, Gbyli R, Kwan J, Won $\mathrm{CH}$, Dela Cruz C, Price C, Koff J, King BA, Rinder HM, Wilson FP, Hwa J, Halene S, Damsky W, van Dijk D, Lee AI, Chun HJ (2021) A neutrophil activation signature predicts critical illness and mortality in COVID-19. Blood Adv 5(5):1164-1177

33. van der Voort PHJ, Moser J, Zandstra DF, Muller Kobold AC, Knoester M, Calkhoven CF, Hamming I, van Meurs M (2020) Leptin levels in SARS-CoV-2 infection related respiratory failure: A cross-sectional study and a pathophysiological framework on the role of fat tissue. Heliyon. 6(8):e04696

34. Kearns SM, Ahern KW, Patrie JT, Horton WB, Harris TE, Kadl A (2021) Reduced adiponectin levels in patients with COVID19 acute respiratory failure: A case-control study. Physiol Rep 9(7):e14843

35. Maurya R, Sebastian P, Namdeo M, Devender M, Gertler A (2021) COVID-19 Severity in obesity: leptin and inflammatory cytokine interplay in the link between high morbidity and mortality. Front Immunol 12:649359

36. Lowery SA, Sariol A, Perlman S (2021) Innate immune and inflammatory responses to SARS-CoV-2: Implications for COVID-19. Cell Host Microbe 29(7):1052-1062
37. Cook JR, Ausiello J (2021) Functional ACE2 deficiency leading to angiotensin imbalance in the pathophysiology of COVID-19. Rev Endocr Metab Disord. https://doi.org/10.1007/s11154-02109663-z:1-20

38. Mkaddem SB, Christou I, Rossato E, Berthelot L, Lehuen A, Monteiro RC (2014) IgA, IgA receptors, and their anti-inflammatory properties. Curr Top Microbiol Immunol 382:221-235

39. Lean FZX, Lamers MM, Smith SP, Shipley R, Schipper D, Temperton N, Haagmans BL, Banyard AC, Bewley KR, Carroll MW, Brookes SM, Brown I, Nuñez A (2020) Development of immunohistochemistry and in situ hybridisation for the detection of SARS-CoV and SARS-CoV-2 in formalin-fixed paraffin-embedded specimens. Sci Rep 10(1):21894

40. Huang N, Pérez P, Kato T, Mikami Y, Okuda K, Gilmore RC, Conde CD, Gasmi B, Stein S, Beach M, Pelayo E, Maldonado JO, Lafont BA, Jang SI, Nasir N, Padilla RJ, Murrah VA, Maile R, Lovell W, Wallet SM, Bowman NM, Meinig SL, Wolfgang MC, Choudhury SN, Novotny M, Aevermann BD, Scheuermann RH, Cannon G, Anderson CW, Lee RE, Marchesan JT, Bush M, Freire M, Kimple AJ, Herr DL, Rabin J, Grazioli A, Das S, French BN, Pranzatelli T, Chiorini JA, Kleiner DE, Pittaluga S, Hewitt SM, Burbelo PD, Chertow D, Frank K, Lee J, Boucher RC, Teichmann SA, Warner BM, Byrd KM (2021) SARS-CoV-2 infection of the oral cavity and saliva. Nat Med 27(5):892-903

41. Massoth LR, Desai N, Szabolcs A, Harris CK, Neyaz A, Crotty R, Chebib I, Rivera MN, Sholl LM, Stone JR, Ting DT, Deshpande V (2021) Comparison of RNA In Situ Hybridization and Immunohistochemistry Techniques for the Detection and Localization of SARS-CoV-2 in Human Tissues. Am J Surg Pathol 45(1):14-24

Publisher's Note Springer Nature remains neutral with regard to jurisdictional claims in published maps and institutional affiliations.

\section{Authors and Affiliations}

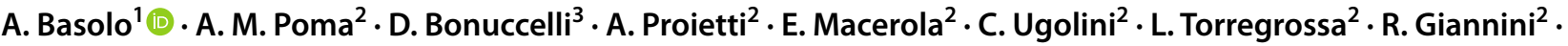 P. Vignali ${ }^{2} \cdot$ F. Basolo ${ }^{2} \cdot$ F. Santini ${ }^{1} \cdot$ A. Toniolo ${ }^{4}$}

\author{
A. M. Poma \\ marcellopoma@gmail.com \\ D. Bonuccelli \\ diana.bonuccelli@uslnordovest.toscana.it \\ A. Proietti \\ agneseproietti@gmail.com \\ E. Macerola \\ elisabetta.macerola@for.unipi.it \\ C. Ugolini \\ clara.ugolini@gmail.com \\ L. Torregrossa \\ libo.torregrossa@gmail.com \\ R. Giannini \\ riccardo.giannini@dc.unipi.it \\ P. Vignali \\ paola.vignali@phd.unipi.it
}

F. Basolo

fulvio.basolo@med.unipi.it

F. Santini

ferruccio.santini@unipi.it

A. Toniolo

antonio.toniolo@gmail.com

1 Obesity and Lipodystrophy Center, Endocrinology Unit, University Hospital of Pisa, 56124 Pisa, Italy

2 Department of Surgical, Medical, Molecular Pathology and Critical Area, University Hospital of Pisa, Pisa, Italy

3 Department of Forensic Medicine, Azienda USL Toscana Nordovest, Lucca, Italy

4 Global Virus Network, University of Insubria, 21100 Varese, Italy 